\title{
Do Auditor Professional Scepticism and Client Narcissism Affect Fraud Risk Assessment?
}

\author{
RIJADH DJATU WINARDI* \\ ARIZONA MUSTIKARINI \\ Universitas Gadjah Mada \\ YOGA PERMANA \\ Risk Advisory, PT Deloitte Kosultan Indonesia
}

\begin{abstract}
This study investigates the effect of professional skepticism and client narcissism on auditors' fraud risk assessment. Financial reporting fraud has become a concern for auditors as part of their responsibility. Auditors are expected to assess the risk of fraud as well as its impact on financial reporting. During fraud risk assessment, several factors can influence auditors, namely professional skepticism as an internal factor and client's narcissism as an external factor. Professional skepticism is related to the level of details and awareness to conduct assessment work. Narcissistic clients are more likely to demonstrate higher inherent and control risk. The purpose of this study is to investigate the effect of professional skepticism and client narcissism on auditors' fraud risk assessment. This study employs a $2 \times 2$ between-subjects experimental design, where professional skepticism and client narcissism are manipulated into are high and low level. The participants in this study are 107 accounting students from undergraduate, master, and professional program in a major university in Indonesia. The results of this study suggest that auditors with a higher level of professional skepticism are more sensitive to the higher incident of fraud and client's narcissism positively affect auditors' assessment of fraud risk. This study contributes to the current fraud risk assessment literature, particularly within Indonesian auditing profession.
\end{abstract}

Keywords: Auditing, Fraud Risk Assessment, Professional Skepticism, Client Narcissism

Intisari: Penelitian ini menyelidiki efek skeptisisme profesional dan narsisme klien pada penilaian risiko penipuan auditor. Pelaporan keuangan penipuan telah menjadi perhatian bagi auditor sebagai bagian dari tanggung jawab mereka. Auditor diharapkan untuk menilai risiko penipuan serta dampaknya pada pelaporan keuangan. Selama penilaian risiko penipuan, beberapa faktor dapat mempengaruhi auditor, yaitu skeptisisme profesional sebagai faktor internal dan narsisisme klien sebagai faktor eksternal. Skeptisisme profesional terkait dengan tingkat rincian dan kesadaran untuk melakukan pekerjaan penilaian. Klien narsistik lebih mungkin untuk

* Corresponding author: rijadh.winardi@ugn.ac.id 
menunjukkan risiko yang melekat dan kontrol yang lebih tinggi. Tujuan dari penelitian ini adalah untuk menyelidiki efek skeptisisme profesional dan narsisisme klien pada penilaian risiko penipuan auditor. Penelitian ini menggunakan $2 \times 2$ desain eksperimental antar subyek, di mana skeptisisme profesional dan narsisisme klien dimanipulasi menjadi tinggi dan rendah. Para peserta dalam penelitian ini adalah 107 mahasiswa akuntansi dari program sarjana, master, dan profesional di universitas besar di Indonesia. Hasil penelitian ini menunjukkan bahwa auditor dengan tingkat skeptisisme profesional yang lebih tinggi lebih sensitif terhadap insiden penipuan yang lebih tinggi dan narsisisme klien secara positif memengaruhi penilaian auditor terhadap risiko penipuan. Studi ini berkontribusi pada literatur penilaian risiko penipuan saat ini khususnya dalam profesi audit Indonesia.

Kata Kunci: Audit, Penilaian Risiko Fraud, Skeptisisme Profesional, Narsisme Klien

\section{Introduction}

For two decades, fraudulent financial reporting has led to financial and nonfinancial losses for society. The Ernst \& Young (2015) survey shows that 37\% of respondents believe companies in their country have presented false financial statements. The case of Enron, WorldCom, Tyco, and Symbol Technologies provide a valuable lesson on how fraudulent severe financial reporting (Schilit \& Perler, 2010). Therefore, companies are required to be more concerned with their governance, and at the same time, external auditors are expected to play a more role in preventing fraud from occurring in the future.

The phenomenon of fraudulent financial reporting is also a concern of the accounting profession in Indonesia (IAPI, 2011). The Indonesian Institute of Certified Public Accountants regulates an assessment regarding the risk of fraud for external auditors by issuing Auditing Standard Section 240. The responsibility of external auditors to obtain reasonable assurance that financial statements are free from material misstatements is equal either due to fraud or error (ISA 200). However, ISA 240 states that the risk of not detecting a material misstatement due to fraud is higher than the risk of not detecting a material misstatement from error.

Prior studies have documented several factors affecting fraud risk assessment. Knapp \& Knapp (2001) reveal that auditors' experience and competency affects the 
effectiveness of fraud risk assessment. More experienced auditors will have more effective fraud risk assessment using analytical procedures (Knapp \& Knapp, 2001). Effective communication within audit team is also another factor affecting the effectiveness of fraud risk assessment. Carpenter (2007) argues that an audit team's brainstorming improves the quality of fraud risk assessment, particularly when fraud exists. Besides competency and communication, auditors' professional skepticism is a significant contributing factor affecting fraud risk assessment (Popova, 2012). Nelson (2009) explains that auditors' knowledge and character are related to their professional skepticism level. Auditors who lack experience and during their career have never discovered any fraud, professional skepticism becomes crucial (Payne \& Ramsay, 2005).

Auditors may use a red flag as a signal of fraudulent financial reporting in determining the risk of fraud. A red flag is a common and useful tool which used in audit process particularly to detect fraud. Client's behavior affects auditors in capturing these red flags. Hamilton (2016) finds that auditors who consider the perspective of a client manager responsible for financial statements are more sensitive in assessing the fraud risk. Client narcissism is also another example of red flags (Johnson et al., 2013). Narcissism is a deviant personal characteristic and is found in various individuals (Paulhus \& Williams, 2002). Narcissism can manifest in multiple forms, such as intellectual performance, interest in particular physical, dominance and general orientation (Morf \& Rhodewalt, 2001).

Client narcissism is the focus of this study. Prior studies on audit judgment topic have been explicitly highlighting the unethical behavior that potentially arises when narcissistic leaders such as Chief Executive Officer (CEO) take organizational control. Although narcissistic leaders may drive organizations to succeed (Morf \& Rhodewalt, 2001), they also prone to engage in a questionable act or create bias in company performance (Marquez-Illescas et al., 2018). Narcissistic leaders can harm organizations because they are "likely to overestimate their abilities and also to make inappropriately risky decisions' (Campbell et al., 2011). Moreover, narcissistic individual, characterized by lower in integrity than non-narcissists, have high self- 
The Indonesian Journal of Accounting Research - Jan, Vol. 20 , No.1 , 2017.

esteem, and dominance (O’Reilly et al., 2017) and likely to exploit others (Rauthmann, 2012). It is important to note that narcissistic can be positive (functional, normal, and constructive) or negative (dysfunctional, pathological, or destructive) (Godkin \& Allcorn, 2011).

Those characteristics are potential red flags for auditor. Chatterjee \& Hambrick (2007) find an association between narcissistic indicators of CEO such as photographs in annual reports and use of first-person pronouns with risky actions that may be taken by the CEO. A person who has a high level of narcissism will focus more on the ultimate goal achieved than the process of achieving that goal (Furtner et al., 2011; Morf \& Rhodewalt, 2001).

The arguments above explain the internal and external factors that influence the external auditor's assessment of fraud risk. Auditor's professional skepticism is considered as an internal factor and client narcissism as an external factor. Professional skepticism makes auditors more sensitive to material misstatements caused by fraud, and they make a better judgment about fraud risk assessment (Fatmawati et al., 2018). While client narcissism can encourage the client to cheat, therefore auditors need to be more attentive in seeing narcissism.

This study is motivated by extant literature on the importance of fraud risk assessment as a fraud detection mechanism (Knapp \& Knapp, 2001). The purpose of this study is to understand the influence of two factors, namely professional skepticism and client narcissism on the fraud risk assessment. This study aims to seek for a generalisation from prior studies which support the hypotheses that professional skepticism and client narcissism have significant effect on auditor fraud risk assessment (e.g., Beasley et al. (2001); Amernic \& Craig (2010); Hammersley (2011); Popova (2012); Rijsenbilt \& Commandeur (2013); Johnson et al. (2013); and Fatmawati et al. (2018)). Prior studies have been undertaken dominated within the context of developed countries (e.g., Popova (2012) and Johnson et al. (2013)). However, limited studies around this issue, especially on client narcissism towards fraud risk assessment is further examined within the context of developing countries, such as Indonesia. Therefore, this study contributes to the additional literature on the 
particular issue for developing countries. Indonesia has different audit environment especially the socio-political context. Moreover, narcissism is a growing phenomenon in Indonesia but obtained a lack of attention from accounting scholars. The association between narcissism behavior and fraud behavior is essential to study in a country with a high incident of corruption.

\section{Theoretical Framework and Hypotheses Development}

\subsection{Audit Judgement and Fraud Risk Assessment}

A fraud risk assessment is required by auditing standards to be undertaken to aim the objective of financial statements audit (IAPI, 2011; ISA 240, SAS 99). It is a process of assessing the risk of material misstatement in fraudulent financial statements (Arens et al., 2017). This assessment is a method to assist in determining the scope of audit procedures related to the type and magnitude of fraud risk in an organization (Vona, 2011). The assessment was performed by the external auditor as the responsibility for the prevention of material misstatement due to fraud during the audit process (IAPI, 2011). Auditors seek information on which part of the financial statements or business processes that are susceptible to fraud (Vona, 2011). The fraud risk assessment is essential to determine the scope of audit procedures to be performed (IAPI, 2011). The external auditor has limitations because it is impossible to change the client's risk condition. Hence auditors should perform risk assessment procedures (Arens et al., 2017). At the same time, fraud risk assessment is a tool for auditors in the event of future legal issues concerning fraudulent financial reporting (Arens et al., 2017; IAPI, 2011). The assessment process begins by identifying the form or scheme of fraud that an organization may encounter (Vona, 2011). She explains that in the assessment of the risk of fraud, auditors and other interested parties can be assisted to formulate the risk of fraud with three questions, such as what are the risks of fraud have been identified? What are the internal controls related to the risk of cheating? Has the risk of fraud been reduced to an acceptable level? Then, this assessment will be updated when the auditors have finished evaluating audit evidence (Hammersley, 2011). 
In Indonesia, the Auditing Standards (AS) Section 240 specifically requires the auditor to assess the possibility of misstatement due to fraud. Auditors need to consider misstatements arising from the consequences of fraudulent financial reporting and misstatements arising from misappropriation of assets (IAPI, 2011). The risk assessment of fraud is a cumulative process, so it should be performed continuously at the various phases of an existing audit. Moreover, Statements on Auditing Standards (SAS) 99 requires discussion among members of the audit team at the time of fraud risk assessment. Through the discussions, new ideas or ideas can be gained because of the various thoughts issued by each member of the audit team (AICPA, 2002). Although the number of ideas will be reduced because it focuses on a few things, but the results of the discussion became more reliable and maintained to a high standard (Carpenter, 2007). External auditors who play an essential role during the audit process have responsibility for fraud prevention under AS Section 315 (IAPI, 2011). Auditors seek information on which part of the financial statements or business processes that are susceptible to fraud (Vona, 2011). According to Johnson et al. (2013), external auditors can do several things, such as identifying narcissistic personality and client behavior as a red flag, considering how observed client behavior can lead to fraud, and incorporating potential fraudulent action with client behavior as an early indication for raising risk assessments.

\subsection{Red Flag}

Romney et al. (1980) and Gullkvist \& Jokipii (2013) define red flags as situational events, pressures, pressures, opportunities, or characteristics that may cause management or employees to engage in fraud on behalf of the company or personal gain. AS Section 315 explains that red flags are beneficial for auditors as they provide warnings about possible fraud. However, the presence of red flags during the audit may not necessarily prove that fraudulent financial reporting has occurred (Albrecht et al., 2015). Smith et al. (2005) indicate that management failure in carrying out internal control function becomes a significant indicator as a fraud detection signal compared to other indicators. Apostolou et al. (2001) conclude that auditors should choose 
management characteristic and influence that exceed its authority as a significant red flag more than operating, financial stability, and industry condition. In a similar vein, Gullkvist \& Jokipii (2013) argue that dishonest or unethical managers are an indication of fraud.

In addition to the commonly used red flags, auditors use other signals that specifically appear in certain circumstances to improve the assessment of suspected fraud (Hammersley, 2011). The occurrence of red flags may come from the client's personality or other factors. When combined with another red flag, this combination will deepen the auditor's understanding of how a client to commit fraud (Hammersley, 2011). Also, Johnson et al. (2013) find that a specific signal of red flags is narcissistic personality, where this narcissism lead to fraudulent behavior in financial reporting (Amernic \& Craig, 2010).

\subsection{Hypotheses Development}

\section{Professional Skepticism}

AS Section 230 states that auditors should consistently question and critically evaluate the existing audit evidence (IAPI, 2011). The standard also requires auditors to be critical of all evidence during the audit process from collection to evaluation phase. Hurtt (2010) defines 'professional skepticism as a multi-dimensional construct that denotes the tendency of each to delay making conclusions to obtain sufficient evidence to support one alternative explanation over another.' This concept is a fundamental concept of skepticism that an auditor needs to possess (Popova, 2012). Professional skepticism is important for the external auditor's assessment of the risk of fraud. Beasley et al. (2001) argue that a lack of professional skepticism is considered as critical factors of fraud risk assessment failure and lead to audit failure. Auditors with high professional skepticism will be more sensitive to material misstatements caused by fraud. As a response to fraud risk, auditors refine the fraud risk assessment by raising or lowering the risk level (AICPA, 2002). Lack of professional skepticism will cause their inability to see any increased risks that have occurred (Hammersley, 
2011). Weakness in performing audit procedure and evaluating audit result is the lack of skepticism and objectivity (PCAOB, 2008).

All members of the audit team should maintain professional skepticism throughout the audit process (Ramos, 2003). This is because someone other than the auditor can influence indirectly professional skepticism. Professional skepticism of an audit partner can affect the assessment of the risk of fraud by the lower authority auditors (Carpenter \& Reimers, 2013). When auditors encounter fraud, they will provide a higher fraud risk assessment when the audit partner also tends to exercise professional skepticism (Carpenter \& Reimers, 2013).

AS Section 240 requires maintaining professional skepticism to current audit regardless of previous experience with the client. However, a study from Popova (2012) reveals that prior experience significantly affects auditors' level of skepticism to determine initial fraud or error rather than auditor's skepticism from their trait. Further, auditors that have a higher level of professional skepticism tend not to be affected by previous experience with client and maintain its professional skepticism to determine the initial fraud/error. Based on the above arguments, this study proposes a hypothesis as follows:

H1. Auditors with a higher level of professional skepticism are likely to assess a higher fraud risk compared to auditors with a lower level of professional skepticism.

\section{Client Narcissism}

The American Psychiatric Association defines narcissism as a personality pattern that has a sense of pride in oneself, self-interest, and a desire for more attention to itself. Narcissism personality tends to bustle with dreams of success, power, beauty, and brilliance. Such personality makes a narcissist live in an interpersonal stage with deviant behavior, demanding the attention and admiration of others. Raskin \& Terry (1988) and Furtner et al. (2011) explain that narcissists may be likely to picturing their achievement, as success comes with (a) preserving an overstated self-view, (b) 
presenting this self-view and success to others, and (c) possibly also debasing others.

A person with narcissism tends to do deviant behavior because of his/her character who expects a positive response from others (Paulhus \& Williams, 2002). Hammersley (2011) argues that a fraud risk assessment that identifies red flags of motivation, opportunity, and rationalization will be further enhanced when combined with specific fraud directives arising from the client, in this case, narcissistic personality. Hence, the narcissistic character can be associated with a fraud risk assessment. Further, Campbell et al. (2004) argue that a person with narcissism makes a risky decision as a form of focus on the success to be achieved. When a manager with narcissism manages to reach the company's target, he/she will get the attention of his/her environment. However, at some stage, it becomes destructive narcissism (Amernic \& Craig, 2010). Individuals with narcissism have a view that their opinion is something that should be prioritized and considered (Campbell et al., 2004).

Financial reporting is a mean of self-actualization for a manager who has a narcissistic personality (Amernic \& Craig, 2010). They argue that achieving published targets to others can be an ideal destination for a narcissistic manager, as with the achievement of the announced target's managers will get positive responses and attention from others when they reach the goal. Johnson et al. (2013) state that the risk assessment of fraud will be increased if the auditor knows the existence of a narcissistic character of a manager. It provides evidence that the character of narcissism that is owned by a client manager can be used as a means of measurement in assessing the risk of fraud (Johnson et al., 2013). Other examples of narcissistic behaviors are presented in Table 1.

One notable example of a CEO's narcissism related to the occurrence of fraud was the CEO of the Sunbeam company (Schilit \& Perler, 2010). In 1996, Al Dunlap served as the new CEO of Sunbeam because of its reputation. Dunlap was famous for his ability to transform a company with poor financial performance to be a good performance company. Dunlap was very optimistic with $20 \%$ growth and $20 \%$ return on equity target in one year (Anderson \& Tirrell, 2004). However, the market 
conditions, in reality, made it impossible to achieve those target. As a result, he made various fraud schemes to accomplish the goal in late 1996 to early 1998. Schwartz (1991) and Amernic \& Craig (2010) mention that accounting as part of the financial system offers a more significant "narcissistic opportunity" than other management functions such as the operations section.

Table 1.

Example of Narcistic Behaviour

\begin{tabular}{|c|l|l|}
\hline No. & \multicolumn{1}{|c|}{ Example } & \multicolumn{1}{|c|}{ Source } \\
\hline 1. & $\begin{array}{l}\text { The CEO's photo in the annual financial report, the use of first- } \\
\text { person pronouns in the interview, the amount of compensation } \\
\text { received for the achievement of the target. }\end{array}$ & $\begin{array}{l}\text { Chatterjee \& } \\
\text { Hambrick (2007) }\end{array}$ \\
\hline 2. & $\begin{array}{l}\text { Photo of the CEO in the financial statements, acceptance of cash and } \\
\text { non-cash performance incentives. }\end{array}$ & $\begin{array}{l}\text { Olsen et al. } \\
(2014)\end{array}$ \\
\hline 3. & $\begin{array}{l}\text { The compensation the CEO receives, the exposure to the CEO, the } \\
\text { authority of the CEO, and the acquisitions made by the CEO. Of the } \\
\text { four categories are translated into more specific indicators such as } \\
\text { awards, publications, photos in financial statements and specialized } \\
\text { facilities of the company. }\end{array}$ & $\begin{array}{l}\text { Commandeur } \\
(2013)\end{array}$ \\
\hline
\end{tabular}

Rijsenbilt \& Commandeur (2013) posit that there is a positive relationship between narcissism and fraudulent actions. It will be risky if someone with such narcissism has the authority to influence policies to his subordinates (Amernic \& Craig, 2010). This situation needs to be observed by auditors in conducting fraud risk assessment. Johnson et al. (2013) conclude an increase in fraud risk assessment by auditors when managers display narcissistic attitudes. In another word, the narcissism of a client manager can be used as a signal or a red flag in fraud risk assessment. Thus, the following hypothesis is developed, stated in alternate form as follows:

H2. The higher client's narcissism, the higher auditor's assessment of the risk of fraud. 


\section{Conceptual Framework}

This study was conducted using two independent variables which consist of professional skepticism and client narcissism and one dependent variable which is a fraud risk assessment. Previous research on the effect of professional skepticism on risk assessment has been done by (Hurtt, 2010). While the related research on the influence of client's narcissism against fraud risk assessment conducted by Johnson et al. (2013). Several studies related to professional skepticism and narcissism were also carried out by Anderson \& Tirrell (2004), Campbell et al. (2004), Chatterjee \& Hambrick (2007), Nelson (2009), Amernic \& Craig (2010), and Carpenter \& Reimers (2013). The conceptual framework of this study developed is illustrated in Figure 1.

Figure 1.

Conceptual Framework

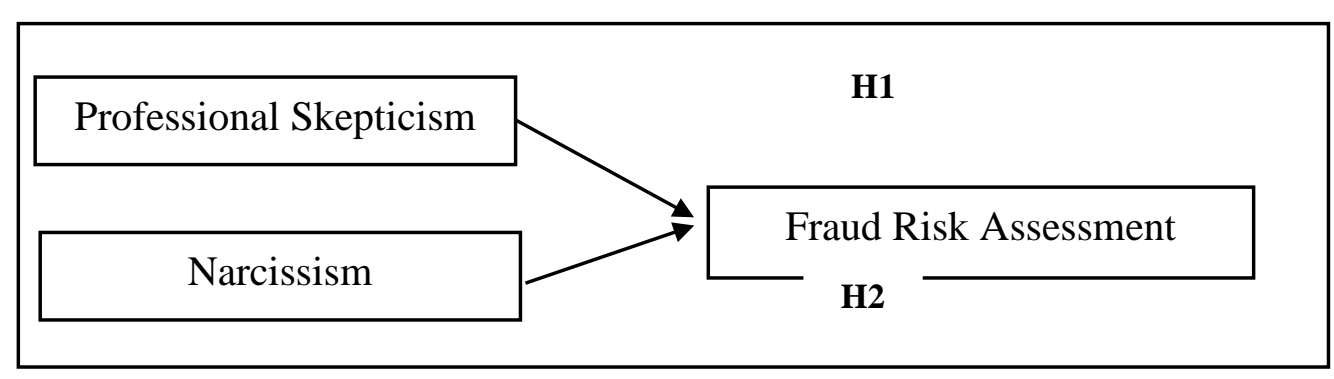

\footnotetext{
${ }^{a}$ Adapted from Hurtt (2010)

${ }^{\mathrm{b}}$ Adapted from Johnson et al. (2013)
}

\section{Research Method}

\subsection{Participants}

The participants in this study are final-year accounting students in the undergraduate, master and professional programs of a major university in Indonesia. Despite there is a serious debate regarding the suitability of student as a surrogate in audit experiment (see Liyanarachchi, 2007), we use them as our participants. Our first arguments are because they understand the basics of accounting to make structured audit judgments (Mortensen, Fisher, \& Wines, 2012). Second, their level of skepticism has not been influenced by other factors that may cause bias (Liyanarachchi, 2007). 
The Indonesian Journal of Accounting Research - Jan, Vol. 20 , No.1 , 2017.

The use of final-year accounting students as a substitution for auditors is also consistent with previous studies (see Chan \& Leung, 2006; Farag \& Elias, 2012; Fleming, Chow, \& Su, 2010)

\subsection{Research Design}

This study uses $2 \times 2$ between-subjects experimental design (See Table 2). There are two independent variables (professional skepticism and client narcissism). Both of these independent variables will be tested for their influence on the dependent variable (external auditor's assessment of fraud risk). The experiment was selected to observe the causal relationship between the independent variable and the dependent variable in relatively higher sureness (Nahartyo, 2012). Another advantage of experimental research is the ability of the researcher in controlling independent variable through manipulation exposure while at the same time, controlling other variables (Nahartyo, 2012). In this experiment, the between-subjects design was chosen because each subject was exposed to different manipulation (Nahartyo, 2012).

Table 2 .

Experimental Design

\begin{tabular}{|c|c|c|c|}
\hline \multicolumn{2}{|c|}{} & \multicolumn{2}{c|}{ Client Narcissism } \\
\cline { 3 - 4 } & High & Low \\
\hline \multirow{2}{*}{$\begin{array}{c}\text { Professional } \\
\text { Skepticism }\end{array}$} & Low & Group 1 & Group 2 \\
\cline { 2 - 4 } & Group 3 & Group 4 \\
\hline
\end{tabular}

The first stage of this experiment was to prepare the research instrument. Instruments were prepared by adopting from Hurtt (2010) for professional skepticism and Johnson et al. (2013) for client narcissism. Pilot tests carried out by the eight undergraduate students to get improvements to the instrument input before the actual research. The third stage is the process of data collection that is part of the real experiment. Implementation of this experiment is done in the classroom by the sample to be taken. When the participants are ready for the experiment, the case scenario is 
shared with the participants randomly. The assistant reads out the procedure before the experiment. The experiment was conducted between April to May 2016. It took approximately 15 minutes to complete the questionnaire.

This study uses the paper and pencil type of experiment. The experiment sheet is divided into several sections. The first part is demographic information such as age, gender, and education. Then the second part contains the measurement of professional skepticism level. The last section includes the case of narcissism. The case is about The Beaumont Construction Company, a company which specializes in commercial and government projects.

\section{Case Development}

This case is adopted from Johnson et al. (2013). Beaumont company provides demolition, site development and construction services on projects ranging from shopping centers to manufacturing facilities such as railroads, pipelines, and other infrastructure projects. The company has long-standing government-owned projects and is limited to small-scale contracts such as for road installations, road construction, and bridges for districts and municipalities. In the scenario, there is an explanation that the company is pursuing aggressive growth.

The case is assumed to be on March 31,2010, with the end of the fiscal year of September 30, 2010, and the entire participants act as an external auditor. Beaumont is a private company and has been a client for the past seven years. Beaumont has about 1,200 employees and has offices in three areas. For the fiscal year ending September 30,2009 , Beaumont reported revenues of $\$ 154.6$ million and a net profit of $\$ 6.7$ million.

Participants will audit the financial statements of 2010 as the first year for participants to audit Beaumont's financial statements. Participants are responsible for the Beaumont Government Projects Group (GPG) project audit. So in the case scenario participants are told to have spent the time to examine the client. One of the information given to the participants is GPG personnel. First, Michael Vance is General Manager of GPG since January 2007. Michael, 34 years old, is a CPA with 
eight years of experience before joining Beaumont. He has experience for three years in a Big Four audit firms, and for five-years, he played a role in the financial and management sections of various construction companies. Other staff members included three contract accountants, Steven Archuleta, Rose Dawson, and Frank Choi; David Williams is a contract supervisor, and Celia McWhorter is the group's administrative assistant. Then the case scenario tells that participants have just met Michael Vance to conduct a business risk assessment. Then given a different conversation as presented in Table 3 .

Table 3.

The Differences of Narcissistic Manipulation

\begin{tabular}{|c|c|}
\hline High Narcissism & Low Narcissism \\
\hline $\begin{array}{l}\text { 1. Michael Vance has worked for a major } \\
\text { construction company and is very proud of his } \\
\text { achievements. }\end{array}$ & $\begin{array}{l}\text { 1. Michael Vance has worked in a } \\
\text { small construction company. }\end{array}$ \\
\hline $\begin{array}{l}\text { 2. Michael Vance actively uses the word "I" in a } \\
\text { conversation with the auditor. }\end{array}$ & $\begin{array}{l}\text { 2. Michael Vance uses the word "us" } \\
\text { more in conversation with the } \\
\text { auditor. }\end{array}$ \\
\hline $\begin{array}{l}\text { 3. Michael Vance recounts the authority and } \\
\text { ability possessed in solving the problem. }\end{array}$ & $\begin{array}{l}\text { 3. Michael Vance recounts the team's } \\
\text { ability to solve problems. }\end{array}$ \\
\hline $\begin{array}{l}\text { 4. Michael Vance displays emotion in response } \\
\text { to questions from auditors. }\end{array}$ & $\begin{array}{l}\text { 4. Michael Vance displays humility in } \\
\text { response to questions from auditors. }\end{array}$ \\
\hline
\end{tabular}

\subsection{Measures}

The dependent variable measurement followed Johnson et al. (2013). The risk assessment of fraud in the case scenario is measured by using a question "Overall, I believe the risk of cheating in this business unit is. . .". The response to this question is measured on a seven-point graph scale, where one indicates "very low", 7 indicates "very high" and number 4 as the midpoint is labeled "medium" (Johnson et al., 2013). 
Professional skepticism was measured using the Hurtt's (2010) scale; the scale has been developed by incorporating six characteristics of professional skepticism. These characteristics include questioning mind, suspension of judgment, search for knowledge, interpersonal understanding, autonomy, and self-esteem. The measurement consists of 30 items of statements which using 6 points Likert scale where the description is 'strongly disagree' to 'strongly agree'. Statements 1, 10, 11, $16,17,19,25$ and 26 are reverse coded. The participants' answers are accumulated with the lowest total score is 30 , and the highest total score is 180 . A total value above midpoint, indicates a high degree of skepticism, while a total value below midpoint indicates a low level of skepticism.

Narcissism is a personality pattern that characterized by a sense of pride in oneself, self-interest, and a desire for more attention to itself (Morf \& Rhodewalt, 2001). In the case scenario, there is a conversation between the auditor and the client manager by raising (or not raising) the conversation signal from the manager with high narcissism (or low narcissism). The signals in the conversation of the manager are raised according to the narcissism indicators used in Johnson et al. (2013). Manager with high narcissism can be exemplified by reflecting on the nature of dominance (I make sure that everything can be completed on time, I tell you it's not easy), authority (my staff is small, I keep them busy) and exploitation (I tell my staff that they are better off following my procedure from now on). Also, in high managerial narcissism used the selection of first-person pronouns (me, I) when speaking in a conversation scenario and the tendency to react angrily (Johnson et al., 2013).

After the participants finished reading the case scenario and assessed the risk of fraud, participants responded to the general manager's character without being allowed to reread the case scenario. The responses given by the participants were measured on a seven-point Likert scale, where 1 = "strongly agree", 4 = "neutral", and 7 = "strongly disagree". The statement B, E, and F are reverse coded. Statements that are not related to narcissism are also included with the purpose of hiding the manipulation. The main goal is to make sure that the participants have internalized the case scenario. Summary of variables measured is presented in Table 4 . 
The Indonesian Journal of Accounting Research - Jan, Vol. 20 , No.1 , 2017.

Table 4.

Variable Measurement

\begin{tabular}{|c|c|c|}
\hline No. & Variable & Measurement \\
\hline 1. & $\begin{array}{l}\text { Fraud Risk } \\
\text { Assessment }\end{array}$ & $\begin{array}{ll}\text { - } & \text { 7-point Likert scale } \\
\text { - } & 1=\text { "Very Low", } 4 \text { = "Medium", and } 7=\text { "Very High" }\end{array}$ \\
\hline 2. & $\begin{array}{l}\text { Professional } \\
\text { Skepticism }\end{array}$ & $\begin{array}{l}\text { - Consists of } 30 \text { items of statements with a } 6 \text { point Likert scale. } \\
\text { - The scale consists of "Strongly Disagree", "Disagree", "Less } \\
\text { Agree", "Somewhat Agree", "Agreed" and "Strongly Agree." } \\
\text { - Specific statements of numbers } 1,10,11,16,17,19,25 \text {, and } 26 \text { are } \\
\text { reverse coded. }\end{array}$ \\
\hline 3. & Client Narcissism & $\begin{array}{ll}\text { - } & \text { Consists of } 8 \text { statements with a } 7 \text { point Likert scale. } \\
\text { - } & \text { Statement number B, E, and F are reverse coded. } \\
\text { - } & 1 \text { indicates "Strongly Agree", } 4 \text { indicates "Neutral" and } 7 \text { indicates } \\
& \text { "Strongly Disagree." }\end{array}$ \\
\hline
\end{tabular}

The experimental data were processed using a statistic test tool SPSS 21 to know the effect of the independent variables on the dependent variable. The hypotheses are tested by using two ways Analysis of Variance (ANOVA) in a significance level of 0.05. We also examined the research instrument to make sure its reliability and validity. Lastly, to see whether the participants had internalized the case, we conduct a manipulation test by using the Independent T-Test.

\subsection{Data Analysis}

\section{Descriptive Statistic and Manipulation Check}

A total number of participants in the study are 171 which consist of undergraduate, master and professional program. However, 64 questionnaires cannot be analyzed because the participants are not filled out. We exclude this questionnaire from the final dataset and resulting 107 questionnaires for further analysis. $49.5 \%$ of the participants are from undergraduate students, $43 \%$ of the total participants are master students, while the rest are from the professional accounting students. 
There are four different groups as a result of participant randomization. Group one is for participants who have a high level of skepticism and acquires high narcissistic manipulation; this group consists of 24 participants. Group two for participants with a high level of skepticism and low narcissism manipulation composed of 25 participants. Group three consists of 32 participants from participants who have a low level of skepticism and acquired high narcissistic manipulation. Group four consists of 26 participants with a low level of skepticism and low narcissism manipulation. The demographic characteristics of the participants are presented in Table 5.

Tabel 5.

Participant Demographics

\begin{tabular}{|c|c|c|c|}
\hline Characteristic & Level & Frequency & Percentage \\
\hline \multirow{6}{*}{ Age } & $15-20$ & 35 & 32,7 \\
\hline & $21-25$ & 61 & 57 \\
\hline & $26-30$ & 5 & 4,7 \\
\hline & $31-35$ & 3 & 2,8 \\
\hline & $36-40$ & 3 & 2,8 \\
\hline & Total & 107 & 100 \\
\hline \multirow{3}{*}{ Sex } & Female & 32 & 29,9 \\
\hline & Male & 75 & 70,1 \\
\hline & Total & 107 & 100 \\
\hline \multirow{4}{*}{ Education } & Undergraduate & 53 & 49,5 \\
\hline & Master & 46 & 43 \\
\hline & Professional Program & 8 & 7,5 \\
\hline & Total & 107 & 100 \\
\hline \multirow{3}{*}{ Professional Scepticism } & Low & 58 & 54,2 \\
\hline & High & 49 & 45,8 \\
\hline & Total & 107 & 100 \\
\hline
\end{tabular}


The Indonesian Journal of Accounting Research - Jan, Vol. 20, No.1 , 2017.

\begin{tabular}{|c|l|c|c|}
\hline Characteristic & \multicolumn{1}{|c|}{ Level } & Frequency & Percentage \\
\hline \multirow{4}{*}{ Client Narcissism } & Low & 51 & 47,7 \\
\cline { 2 - 4 } & High & 56 & 52,3 \\
\cline { 2 - 4 } & Total & $\mathbf{1 0 7}$ & $\mathbf{1 0 0}$ \\
\hline \multirow{4}{*}{ Experimental Group } & Group 1 & 24 & 22,4 \\
\cline { 2 - 4 } & Group 2 & 25 & 23,4 \\
\cline { 2 - 4 } & Group 3 & 32 & 29,9 \\
\cline { 2 - 4 } & Group 4 & 26 & 24,3 \\
\cline { 2 - 4 } & Total & $\mathbf{1 0 7}$ & $\mathbf{1 0 0}$ \\
\hline
\end{tabular}

We conduct the validity and reliability tests on Hurtt's skepticism scale statements before hypotheses testing. Analysis of correlation (Corrected Item-Total Correlation) is used for validity testing. To test the 107 samples and 30 statements, the value of $r$ tables required is 0.190. Most of our result is above the required value. Therefore it can be concluded that the items in the questionnaire are valid. However, there are two statements (11 and 13) on professional skepticism which should be eliminated because they are below the required value. An instrument is reliable if the Cronbach's Alpha value of more than 0.6 (Sekaran \& Bougie, 2016). Cronbach's Alpha value for professional skepticism is 0.866 and 0.610 for client narcissism. Therefore, we conclude that the measurement model is reliable.

Manipulation is a significant part of an experiment because it will determine the validity of the research (Nahartyo, 2012). Participants with successful manipulation will be considered feasible to continue the experiment and data obtained can be processed further (Nahartyo, 2012). We employed manipulation check by using Independent T-Test. There is one statement (Statement E) which was inserted in the questionnaire to find out whether the case has been internalized. Furthermore, before testing the hypotheses; the participants' scores for their answer for narcissism questions are calculated. The manipulation classification is taken by finding the average of the participant's answer. Low categories are given when participants score 
below average and vice versa. We concluded that participants had internalized the case of client narcissism because the test shows $p$-sig. 0.021. Participants who received low narcissism had an average answer of 4.64 and participants who had high narcissism had an average answer 5.16 (See table 6 for the test result).

Table 6.

Independent Samples T Test Result

\begin{tabular}{|l|c|c|c|c|}
\hline $\begin{array}{c}\text { Client } \\
\text { Narcissism }\end{array}$ & N & \multicolumn{1}{c|}{ Mean } & df & Sig. \\
\cline { 1 - 4 } Low & 39 & 4.6410 & \multirow{2}{*}{105} & .021 \\
\cline { 1 - 4 } High & 68 & 5.1618 & & \\
\hline
\end{tabular}

\section{Hypotheses Testing}

To test the hypothesis, an ANOVA is used. There are two hypotheses to be tested and is explained as in Table 7.

Table 7.

Hypotheses Testing

\begin{tabular}{|c|c|c|c|c|c|}
\hline & $\begin{array}{l}\text { Type III Sum of } \\
\text { Squares }\end{array}$ & df & $\begin{array}{l}\text { Mean } \\
\text { Square }\end{array}$ & $\mathbf{F}$ & Sig. \\
\hline Professional Skepticism & 7.303 & 1 & 7.303 & 6.190 & .014 \\
\hline Client Narcissism & 6.106 & 1 & 6.106 & 5.175 & .025 \\
\hline $\begin{array}{l}\text { Professional Skepticism * } \\
\text { Client Narcissism }\end{array}$ & .881 & 1 & .881 & .747 & .389 \\
\hline
\end{tabular}

a. R Squared $=.099$ (Adjusted R Squared $=.073$ )

The objective of $\mathrm{H} 1$ is to examine whether professional skepticism influences the participants' fraud risk assessment. H1 predicts that participants with higher levels of skepticism are more likely to give higher fraud risk assessment. The results of the first hypothesis test show that participants who have high levels of professional skepticism 
tend to provide a higher risk assessment of fraud than participants who have low professional skepticism. As shown in Table 6, professional skepticism significantly affects fraud risk assessment $(\mathrm{F}=6.190 ; \mathrm{Sig} .=0.014)$. Hence, it can be concluded that hypothesis 1 is supported.

In $\mathrm{H} 2$, we investigate whether the participants who acquired high client narcissism treatment will give a higher fraud risk assessment than those with low client narcissism treatment. Table 6 reports the empirical results for this hypothesis. Consistent with our expectations, client narcissism is positively and statistically significantly associated with fraud risk assessment. It can be concluded that narcissism manipulation obtained by the participants have a significant effect on their fraud risk assessment with $\mathrm{F}=5,175$ and Sig. $=0,025$. Therefore, it can be concluded that hypothesis $\mathbf{2}$ is supported.

\section{Result and Discussion}

This study extends previous studies on fraud risk assessment by examining auditor's scepticism and client narcissism especially within the context of developing countries. This study is designed mainly in response to third social realities. First, fraud in Indonesia is a recurring problem within government and business institution (Prabowo and Cooper, 2016). Second, narcissism is the emerging social phenomena within Indonesian socio-political environment (Lasch, 1991). Third, there are more pressures on the auditing profession due to massive audit failures in detecting material misstatements from fraud or any illegal acts by the management. Confronting these realities, experimental based research was conducted to understand the role of the professional skepticism and narcissistic client behavior on auditors' overall fraud risk assessment.

Professional scepticism is a critical part for auditors in assessing the risk of

fraud. Beasley et al. (2001) argue that a lack of professional scepticism can cause an audit failure. This study provides empirical evidence that the more sceptical auditors, the more sensitive he or she in assessing the fraud risk. Our finding is consistent with 
previous studies undertaken in developed countries (e.g., Hurrt, 2010; Hammersley, 2011; and Popova, 2012).

Besides the internal factor, we examine the external factor that affects the auditors' fraud risk assessment, namely client narcissism. The results of this study show that auditors will capture high client's narcissism as a sign of possible fraud behavior. The auditors perceive narcissism not as a neutral behavior instead they see it as an indication that the client exhibited domination over power in the organization. Although, it may be reasonable to hold a position that there is no narcistic behavior not always relate to corrupt act only exist as early possible sign of fraud. Consistent with literature (e.g., Amernic \& Craig, 2010; Johnson et al., 2013; and Rijsenbilt \& Commandeur, 2013), our results indicate that client who exhibits narcissistic behavior will be seen as a red flag by the auditors. Alternatively, this could be viewed as the dark side of narcissistic personality. Even there is a positive side, but many researchers found that narcissistic is closer to negative consequence for an organization involved in a lawsuit (O'Reilly et al., 2017), fraud incident (Johnson et al., 2013), and bias on company disclosure (Marquez-Illescas et al., 2018).

\section{Conclusions, Implications, and Limitations}

Apart from the various limitations encountered while performing the audit function, auditors are always expected to provide a high-quality audit. Therefore, auditors need to maintain their professional skepticism at any time during the audit assignment (Nelson, 2009). To provide a high-quality audit, they have to provide accurate fraud risk assessment. The assessment will depend on auditors' professional skepticism as an internal factor. Hammersley (2011) argues that low skepticism will cause the auditor's inability to see any increased risks that have occurred. The auditor's professional skepticism is important for the assessment of fraud risk. Auditors are increasingly sensitive to the possibility that a material misstatement is caused by fraud. This is undertaken by refining the fraud risk assessment by raising or lowering the risk level (AICPA, 2002). Hurtt (2010) explains that skepticism will influence auditors' mind and behavior, such as in the evidence evaluation and when they make 
alternative arguments. Moreover, skepticism is sitgnificant for auditors to help them obtaining additional information about contradictory information and unintentional mistakes (Hurtt et al., 2008).

For the accounting profession in Indonesia specifically, this study provides more emphasis on the importance of professional skepticism for auditors. Policy makers or professional bodies should put more attention on auditors' professional skepticism. For example by providing more training for auditors to enhance their level of professional skepticism (Hurtt, 2010) or encourage universities to improve their accounting profession program for accounting students who wish to pursue a career as an auditor (Fatmawati et al., 2018).

Narcissism becomes a phenomenon of personality that emerged in the society, ranging from lower to top class. Narcissism can manifest in various forms, such as intellectual performance, dominance and general orientation (Morf \& Rhodewalt, 2001). Narcissistic individuals have a continuous necessity to emphasize their magnificent self-image. Auditors should consider the personality of a person with narcissism as an essential red flag in a fraud risk assessment. Paulhus \& Williams (2002) argue that narcissism personality tends to be misbehaving because of the nature of narcissism that always wanted a positive response. Client narcissism has not been used as a red flag by professional policy-makers, but according to Hammersley (2011) fraud risk assessment that identifies red flags of motivation, opportunity, and rationalization can be increased when combined with specific fraud sign arising from clients such as narcissistic personality. In a previous study, Johnson et al. (2013) explain that the risk assessment of fraud will be increased if the auditor is aware of the narcissistic character of a manager. The auditor will judge the level of the narcissism of a client as a form of personality that can rationalize the fraud happening (Johnson et al., 2013). Johnson et al. (2013) also conclude that the risk assessment of fraud would be higher when there is fraudulent motivation from the client.

For practical implication to auditing profession in Indonesia, the phenomenon of narcissism can serve as a new red flag in conducting fraud risk assessment. Given the relationship between client narcissism and increased risk of fraud, these findings 
provide some consideration for policymakers to improve existing professional guidelines.

\subsection{Conclusion}

This study aims to investigate whether internal and external factors of auditors can influence the auditors' decision making related to fraud risk assessment. The results show that professional skepticism significantly influences the assessment of external auditors on fraud risk. The results of this study are consistent with previous studies (Hurtt, 2010; Popova, 2012). Thus, it can be concluded that professional skepticism may influence the risk assessment of fraud. It is critical that external auditors should maintain professional skepticism to provide a high-quality audit. Also, this study finds that client narcissism significantly influences the external auditor's assessment of fraud risk. The results of this study result are consistent with previous research (e.g., Johnson et al., 2013). Thus, auditors should be more observant regarding client's narcissism as one of the red flags need to be considered when conducting a fraud risk assessment.

This study cannot be separated from limitations and should be considered in future research. This study uses accounting students from a single major university rather than auditors. This leads to the external validity problem and these students might not have been exposed to real audit practices. Another limitation that readers should interpret from this study is the client's narcissism within this study was only manipulated in the form of the use of the word "I" for high category narcissism and the word "us" for low category narcissism. More expression should be used to capture the complexity of this behavior. Some suggestions for further research include using actual auditors rather than accounting students. Hence, further research will provide more generalizable information. Using a more interactive research instrument and not only limited in the form of case questionnaires are also other suggestions for future research. This is performed to limit the participants to follow the experiment seriously from the beginning to the end of the study. 
The Indonesian Journal of Accounting Research - Jan, Vol. 20 , No.1 , 2017.

\section{References}

AICPA. Consideration of Fraud in a Financial Statement Audit, Pub. L. No. 316, AU Section 31652 (2002).

https://www.aicpa.org/Research/Standards/AuditAttest/DownloadableDocuments/AU00316.pdf. Retrieved from

https://www.aicpa.org/Research/Standards/AuditAttest/DownloadableDocuments/AU00316.pdf

Albrecht, W. S., Albrecht, C. O., Albrecht, C. C., \& Zimbelman, M. F. (2015). Fraud Examination. Cengage Learning. Retrieved from https://books.google.co.id/books?id=R6q5BwAAQBAJ

Amernic, J. H., \& Craig, R. J. (2010). Accounting as a Facilitator of Extreme Narcissism. Journal of Business Ethics, 96(1), 79-93. https://doi.org/10.1007/s10551-010-0450-0

Anderson, J. R., \& Tirrell, M. E. (2004). Too Good to Be True CEOs and Financial Reporting Fraud. Consulting Psychology Journal: Practice and Research, 56(1), 35-43. https://doi.org/10.1037/1061-4087.56.1.35

Apostolou, B. A., Hassell, J. M., Webber, S. A., \& Sumners, G. E. (2001). The Relative Importance of Management Fraud Risk Factors. Behavioral Research in Accounting, 13(1), 1-24. https://doi.org/10.2308/bria.2001.13.1.1

Arens, A. A., Elder, R. J., \& Beasley, M. S. (2016). Auditing and Assurance Services. PRENTICE HALL. Retrieved from https://books.google.co.id/books?id=4TAKswEACAAJ

Beasley, M.S., Carcello, J.V \& Hermanson, D.R., 2001. Top 10 audit deficiencies. Journal of Accountancy 19(1): 63-66.

Campbell, W. K., Goodie, A. S., \& Foster, J. D. (2004). Narcissism, confidence, and risk attitude. Journal of Behavioral Decision Making, 17(4), 297-311. https://doi.org/10.1002/bdm.475

Campbell, W. K., Hoffman, B. J., Campbell, S. M., \& Marchisio, G. (2011). Narcissism in organizational contexts. Human Resource Management Review, 21(4), 268-284. https://doi.org/10.1016/J.HRMR.2010.10.007

Carpenter, T. D. (2007). Audit Team Brainstorming, Fraud Risk and Fraud Risk Identification, Assessment : of SAS No 99 Implications. The Accounting Review, 82(5), 1119-1140. https://doi.org/10.2308/accr.2007.82.5.1119

Carpenter, T. D., \& Reimers, J. L. (2013). Professional Skepticism: The Effects of a Partner's Influence and the Level of Fraud Indicators on Auditors' Fraud Judgments and Actions. Behavioral Research in Accounting, 25(2), 45-69. https://doi.org/10.2308/bria-50468

Chan, S. Y. S., \& Leung, P. (2006). The effects of accounting students' ethical reasoning and personal factors on their ethical sensitivity. Managerial Auditing Journal, 21(4), 436- 
457. https://doi.org/10.1108/02686900610661432

Chatterjee, A., \& Hambrick, D. C. (2007). It's All about Me: Narcissistic Chief Executive Officers and Their Effects on Company Strategy and Performance. Administrative Science Quarterly, 52(3), 351-386. https://doi.org/10.2189/asqu.52.3.351

Ernst \& Young. (2015). Europe, Middle East, India and Africa Fraud Survey 2015. London. Retrieved from http://www.ey.com/Publication/vwLUAssets/ey-emeia-fraudsurvey/\$FILE/ey-emeia-fraud-survey.pdf

Farag, M. S., \& Elias, R. Z. (2012). The Impact of Accounting Students' Professional Skepticism on their Ethical Perception of Earnings Management, in Cynthia Jeffrey (ed.) Research on Professional Responsibility and Ethics in Accounting, 16, pp.185 - 200.

Fatmawati, D., Mustikarini, A., and Fransiska, I. P. (2018). Does Accounting Education Affect Professional Skepticism and Audit Judgment? Jurnal Pengurusan, 58, 1-21. http://ejournals.ukm.my/pengurusan/article/view/16757

Fleming, D. M., Chow, C. W., \& Su, W. (2010). An Exploratory Study of Chinese Accounting Students' and Auditors' Audit-specific Ethical Reasoning. Journal of Business Ethics, 94(3), 353-369. https://doi.org/10.1007/s10551-009-0267-x

Furtner, M. R., Rauthmann, J. F., \& Sachse, P. (2011). The Self-Loving Self-Leader: An Examination of the Relationship Between Self-Leadership and the Dark Triad. Social Behavior and Personality: An International Journal, 39(3), 369-379. https://doi.org/10.2224/sbp.2011.39.3.369

Godkin, L., \& Allcorn, S. (2011). Organizational Resistance to Destructive Narcissistic Behavior. Journal of Business Ethics, 104(4), 559-570. https://doi.org/10.1007/s10551$\underline{011-0930-\mathrm{X}}$

Gullkvist, B., \& Jokipii, A. (2013). Perceived importance of red flags across fraud types. Critical Perspectives on Accounting, 24(1), 44-61. https://doi.org/10.1016/J.CPA.2012.01.004

Hammersley, J. S. (2011). A Review and Model of Auditor Judgments in Fraud-Related Planning Tasks. AUDITING-A JOURNAL OF PRACTICE \& THEORY, 30(4), 101-128. https://doi.org/10.2308/ajpt-10145

Hurtt, K. (2010). Development of a scale to measure professional skepticism. Auditing, 29(1), 149-171. https://doi.org/10.2308/aud.2010.29.1.149

Hurtt, K., Eining, M. M., \& Plumlee, D. (2008). An Experimental Examination of Professional Skepticism. SSRN Electronic Journal, (MAY 2008). https://doi.org/10.2139/ssrn.1140267

IAPI. (2011). Standar Profesional Akuntan Publik. Jakarta: Salemba Empat.

Johnson, E. N., Kuhn, J. R., Apostolou, B. A., \& Hassell, J. M. (2013). Auditor Perceptions of 
The Indonesian Journal of Accounting Research - Jan, Vol. 20 , No.1 , 2017.

Client Narcissism as a Fraud Attitude Risk Factor. AUDITING-A JOURNAL OF PRACTICE \& THEORY, 32(1), 203-219.

Knapp, C. A., \& Knapp, M. C. (2001). The effects of experience and explicit fraud risk assessment in detecting fraud with analytical procedures. Accounting, Organizations and Society, 26(1), 25-37. https://doi.org/10.1016/S0361-3682(00)00005-2

Lasch, C. (1991). The Culture of Narcissism: American Life in an Age of Diminishing Expectations. W. W. Norton. Retrieved from https://books.google.co.id/books?id=egsZMX3ZNOC

Liyanarachchi, G. A. (2007). Feasibility of using student subjects in accounting experiments: a review. Pacific Accounting Review, 19(1), 47-67.

https://doi.org/10.1108/01140580710754647

Marquez-Illescas, G., Zebedee, A. A., \& Zhou, L. (2018). Hear Me Write: Does CEO Narcissism Affect Disclosure? Journal of Business Ethics, 1-17. https://doi.org/10.1007/s10551-018-3796-3

Morf, C. C., \& Rhodewalt, F. (2001). Unraveling the Paradoxes of Narcissism: A Dynamic Self-Regulatory Processing Model. Psychological Inquiry, 12(4), 177-196. https://doi.org/10.1207/S15327965PLI1204_1

Mortensen, T., Fisher, R., \& Wines, G. (2012). Students as surrogates for practicing accountants: Further evidence. Accounting Forum. https://doi.org/10.1016/j.accfor.2012.06.003

Nahartyo, E. (2012). Desain dan Implementasi Riset Eksperimen (1st ed.). Yogyakarta: UPP STIM YKPN.

O’Reilly, C. A., Doerr, B., \& Chatman, J. A. (2017). "See You in Court": How CEO narcissism increases firms' vulnerability to lawsuits. The Leadership Quarterly. https://doi.org/10.1016/J.LEAQUA.2017.08.001

Olsen, K. J., Dworkis, K. K., \& Young, S. M. (2014). CEO Narcissism and Accounting: A Picture of Profits. Journal of Management Accounting Research, 26(2), 243-267. https://doi.org/10.2308/jmar-50638

Paulhus, D. L., \& Williams, K. M. (2002). The Dark Triad of personality: Narcissism, Machiavellianism, and psychopathy. Journal of Research in Personality, 36(6), 556-563. https://doi.org/10.1016/S0092-6566(02)00505-6

Payne, E. A., \& Ramsay, R. J. (2005). Fraud risk assessments and auditors' professional skepticism. Managerial Auditing Journal, 20(3), 321-330. https://doi.org/10.1108/02686900510585636

PCAOB. (2008). REPORT ON THE PCAOB'S 2004, 2005, 2006, AND 2007 INSPECTIONS OF DOMESTIC ANNUALLY INSPECTED FIRMS. Washington. Retrieved from www.pcaobus.org 
Popova, V. (2012). Exploration of skepticism, client-specific experiences, and audit judgments. Managerial Auditing Journal, 28(2), 140-160. https://doi.org/10.1108/02686901311284540

Prabowo, H. Y., \& Cooper, K. (2016). Re-understanding corruption in the Indonesian public sector through three behavioral lenses. Journal of Financial Crime, 23(4), 1028-1062. https://doi.org/10.1108/JFC-08-2015-0039

Raskin, R., \& Terry, H. (1988). A principal-components analysis of the Narcissistic Personality Inventory and further evidence of its construct validity. Journal of Personality and Social Psychology, 54(5), 890-902. Retrieved from http://www.ncbi.nlm.nih.gov/pubmed/3379585

Rauthmann, J. F. (2012). The Dark Triad and Interpersonal Perception: Similarities and Differences in the Social Consequences of Narcissism, Machiavellianism, and Psychopathy. Social Psychological and Personality Science, 3(4), 487-496. https://doi.org/10.1177/1948550611427608

Rijsenbilt, A., \& Commandeur, H. (2013). Narcissus Enters the Courtroom: CEO Narcissism and Fraud. Journal of Business Ethics, 117(2), 413-429. https://doi.org/10.1007/s10551$\underline{012-1528-7}$

Romney, M., Albrecht, W., \& Cherrington, D. (1980). Red-flagging the white-collar criminal. Management Accounting, 51-57.

Schilit, H. M., \& Perler, J. (2010). Financial Shenanigans: How to Detect Accounting Gimmicks \& Fraud in Financial Reports, Third Edition. McGraw-Hill Education. Retrieved from https://books.google.co.id/books?id=aUgbK qilgsC

Schwartz, H. S. (1991). Narcissism Project and Corporate Decay: The Case of General Motors. Business Ethics Quarterly, 1(3), 249. https://doi.org/10.2307/3857613

Sekaran, U., \& Bougie, R. (2016). Research Methods For Business: A Skill Building Approach (7th ed.). Chichester: Wiley.

Smith, M., Haji Omar, N., Iskandar Zulkarnain Sayd Idris, S., \& Baharuddin, I. (2005). Auditors' perception of fraud risk indicators. Managerial Auditing Journal, 20(1), $73-$ 85. https://doi.org/10.1108/02686900510570713

Vona, L. W. (2011). The Fraud Audit: Responding to the Risk of Fraud in Core Business Systems. Wiley. Retrieved from https://books.google.co.id/books?id=sH9XkPGYlMEC 
The Indonesian Journal of Accounting Research - Jan, Vol. 20, No.1 , 2017.

intentionally blank 